\title{
To Explore the Relationship of Factors in the Third-Party Logistics Industry using DEMATEL
}

\author{
Ashok. R, Rajesh. R, Surender Kumar
}

\begin{abstract}
The 3PL market is a growing trend around the world, but it is already grown in the UAE, especially in Dubai, where it is having very high market and is growing fast in Abu Dhabi like Dubai. The DEMATEL approach is used to develop an important relationship between dimension and criteria. It uses the matrix and related theories of math to calculate the cause and effect of the degree on each variable. This approach is commonly accustomed to solve various sorts of complex studies which will effectively explain the complex structure and supply the reasonable choices of problem-solving. The primary motivation behind this paper is to break down the components impacting customers' practice in third-party logistics industry by applying DEMATEL strategy. Fourteen factors namely Responsiveness, Reliability of the $3 P L$ provider, Quality of operation, Cost, Flexibility, Financial stability, Delivery time, Ability to meet customer needs, Document accuracy, Storage facilities, Good communication, Attitude towards customers, Technical competence and Reputation are chosen from many different studies. In this research, six experts were involved with a request to evaluate the degree of direct impact between two variables by means of a pair comparison. The results showed the best three significant factors influencing delivery time, quality of operation and cost. Besides, cause and effect connection outlines are additionally built to increase the understanding of the intuitive connection between those criteria. It is discovered that reputation has the most effect on the other factors and cost gets the most effect from different components. At last, this article gives realistic guidelines for the 3PL market in Abu Dhabi, UAE.
\end{abstract}

Keywords: Decision Making Trial and Evaluation Laboratory (DEMATEL), Questionnaire survey, Third-party logistics, Abu Dhabi, UAE.

\section{INTRODUCTION}

Today the third-party logistics industry is booming throughout the world. It is taking the business industry into the next level by reducing the cost and focuses on core competency in the business. The web-based 3PLs with

Revised Manuscript Received on August 15, 2020.

* Correspondence Author

R. Ashok*, Research Scholar, Department of Mechanical Engineering, Noorul Islam Higher Education, Kumara coil, Tamil Nadu, India, E-mail: ashokamalan@gmail.com.

Dr.R. Rajesh, Principal, Rohini College of Engineering \& Technology, Anjugrammam, Tamilnadu, India, E-mail: rajesh1576@yahoo.co.in

Dr. Surender Kumar, Assistant Professor, Jaipuria Institute of Management, Noida, Uttar Pradesh, India. E-mail: skt.ncr@gmail.com

(C) The Authors. Published by Blue Eyes Intelligence Engineering and Sciences Publication (BEIESP). This is an open access article under the CC BY-NC-ND license (http://creativecommons.org/licenses/by-nc-nd/4.0/) extended supply chain integration are taking place from the year 2000 onwards due to huge growth of the 3PL industry. In UAE particularly in Dubai, the 3PL market is the center for the whole world. It brings consideration to all industrialists towards the UAE. Many analysts are analyzing the world's logistics market for third parties and have used different techniques to analyze the data. More than $66 \%$ of the organizations utilized 3PL tasks for local and overall activities. Carrier selection (94.3\%) was the primary outsourced operation of 3PL customers, followed by cost negotiation (88.6\%), freight payment (84.8\%) and consolidation of shipment (82.9\%) [1]. Almost $89 \%$ of the 3PL users have the agreements with their specialist co-ops. Still now, the companies have more tip-up with the service providers due to their business growth. It is good indication for 3PL business in the UAE. The DEMATEL decision making technique is a multiple-attribute decision-making (MADM) tool. In general, the success of the decision-makers ability to evaluate the dynamic cause-effect relationship and take gainful actions depending on the examination. DEMATEL methods can isolate the included criteria of a system into the cause and effect results for helping decisions. This paper comprises of five sections, i.e., Literature survey, Research methodology [Construction of Initial influence matrix, Construction of normalized decision matrix, Construction of total relation matrix, Calculation of $\mathrm{D}+\mathrm{R}$ and D-R], Results and Discussion and Finally, we conclude to managerial implication with our conclusion.

\section{LITERATURE REVIEW}

Much research has been carried out on performance factors for the 3PL industry studies and the DEMATEL method utilized in various fields. In this literature review, few of the fields which have been used by DEMATEL and factors that are notified in the literature review. The factors Delivery performance, flexibility and customer relationship (Rajesh et al; 2013), service quality (Habibullah.K;2017), customer satisfaction (Lianguang;2009), price, reliability, service quality (Aguezzoul;2007) and cost, reliability service quality and financial stability (Bagchi and Virum;1996), cost (Van Laarhoven and Sharman; 1994),service performance and quality (Selviaridis and Spring; 2007), ease of collaboration, money related openings, trustworthiness and quality of operations administration and correct receipt and follow-up of orders (Aktas and Ulengin;

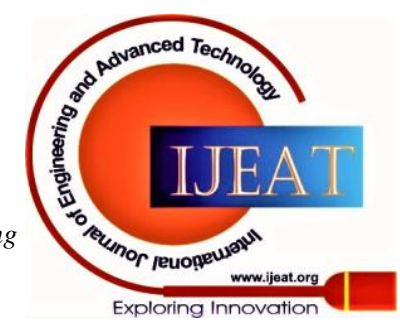


2005),cost and quality (Hwang et al;2016) are the important criterion in the third-party logistics industry[2].Initially, DEMATEL strategy was developed by the Battelle Memorial Institute of Geneva's Science and Human Affairs Program from 1972 to 1979, with the goal of researching the dynamic and intertwined problematic group.

It has been broadly acknowledged the best method to illuminate the cause and effect relationship between the assessment criteria [3].

Kannan. G; 2015 investigated the interrelationships between the threats faced by 3PL expert communities and found that arms-length association between the client and the 3PLs have solid impact on various threats [4]. Steady conveyance of products is the most important and the strongest relation to other criteria [5]. Carbon information management system and carbon management are important criteria for selecting suppliers with carbon management competencies [6]. According to Abdullah. L;2018, convenience is the prime influencing factor than other factors such as product or service details, security and protection [7], ease of use system, and web site reputation in e-commerce. According to EB Leksono;2017, the perspective of innovation and development was the most influencing than other perspective such as economy, consumer, operational and sustainable service knowledge [8]. DEMATEL was also used to solve the internal dependence problems across a variety of parameters set of criteria in different fields, such as identifying influential factors for S \&P 500 index futures, service quality expectation as per predication of service, internal barriers of automotive parts manufacturers, evaluating effects in E-learning programs, multiple criteria that captures the complexity of location planning for collection and distribution centers, criteria selection for renewable energy resources, identification of critical barriers to the sustainable sludge-to-energy development, developing global manager's competencies, identifying critical success factors in emergency management.

\section{RESEARCH METHODOLOGY}

This research method is shown in the Flow chart.1

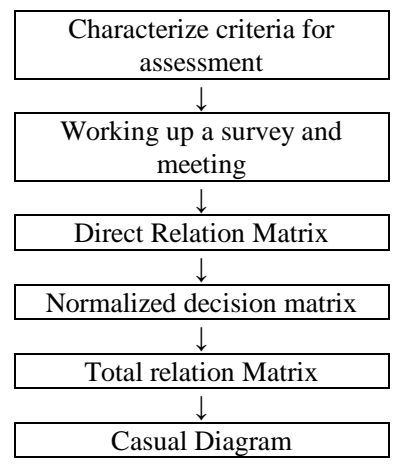

Flow chart-1

\section{A. Define criteria for evaluation}

The factors or the criterions are identified from several articles and evaluation of different 3PL client's and 3PL firm's expectation in 3PL industry in Abu Dhabi, UAE.

\section{B. Developing a questionnaire and interviewing session}

A survey of DEMATEL was constructed utilizing 14 variables. As indicated by Teng (2002), a group decision-making is increasingly applicable with 5 to 15 specialists. And questionnaires were given to six experts in this paper, to assess the relative importance of all the parameters. Six executives, three of them 3PL customers and 3PL firms, each with expertise in third party logistics, who have more than ten a long time of involvement in the logistics field .By evaluating the degree of influence of one factor to the other through a pair wise comparison, each of them was provided with a $14 \times 14$ matrix of direct-relationships. To make this comparison, the experts had expressed their views through variables extending from "no influence" to "very high influence" as mentioned in Table-1

Table-1

\begin{tabular}{|c|c|}
\hline Linguistic terms & Influence score \\
\hline No influence & 0 \\
\hline Low influence & 1 \\
\hline Medium influence & 2 \\
\hline High influence & 3 \\
\hline Very high influence & 4 \\
\hline
\end{tabular}

\section{Dematel method}

The DEMATEL approach is utilizing in constructing interrelations between different variables and to arrive the central object which represents the importance of factors (Fontela and Gabus, 1974, 1976). It has been successfully implemented in numerous fields, for example, marketing campaigns, management systems, safety concerns, enhancing global managers ' abilities and group decision-making (Wu\&Lee;2007).

The DEMATEL is used in this paper to classify thecomple $\mathrm{x}$ relationships and to create an impact-relationship map (IR M)of their parameters,but also to obtain the levels of control of element other. The DEMATEL strategy is utilized to determine the interrelationships between the criteria for creating an IRM.

The process comprises of the following essential measures.

(1) The elements relating to the problem and the degree of influence between the elements are established in this stage reviews, brainstorming, or expert opinions describe the important factors of the complex system.

(2) The matrix shall be built in direct relation. A questionnaire survey method is then carried out after measurement scale values are defined.

(3) A normalized direct relationship matrix is constructed using equation (1) on the basis of a direct relationship matrix.

$$
a_{i j}=\frac{1}{\mathbb{R}} \sum_{\mathrm{i}=\mathbb{1}}^{\mathbb{R}} X^{\mathbb{k}} i j \mathrm{i}_{s} \mathrm{j}=1_{s} 2_{w \ldots s} \mathrm{n} \text {. }
$$

Normalized matrix $\mathrm{N}=\mathrm{A} / \mathrm{s}$

$$
s=\max \lfloor\underbrace{\max }_{1<i<n} \sum_{j=1}^{n} a_{i j} \underbrace{\max }_{1<j<n} \sum_{i=1}^{n} a_{i j}\rfloor
$$

(4)The matrix total relationship (T) is acquired in the form given as;

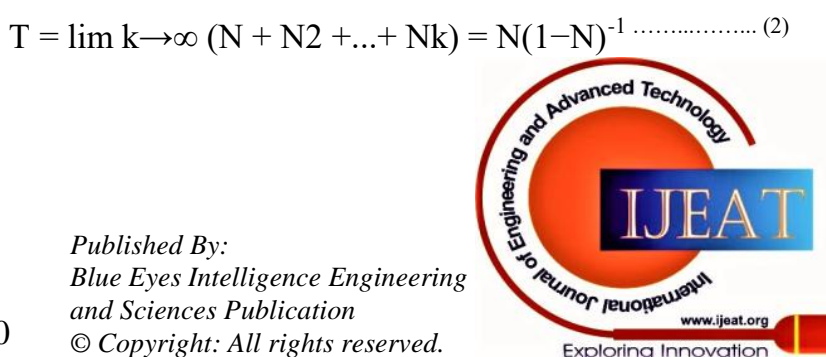


In this step, the value sum in each column and each row is determined in the matrix of the total relation. Therefore, Di shows the sum of the row $\mathrm{i}^{\text {th }}$, and $\mathrm{Rj}$ shows the sum of the column $j^{\text {th }}$, i.e. the direct and indirect effects between the variables respectively.The cause and effect diagram are compiled at this point. Summing $\mathrm{R}$ and $\mathrm{D}$ creates the horizontal axis (D+R), while the vertical axis (D-R) is formed by subtracting $R$ from $D$. Although $(D+R)$ is defined as "prominence" indicating the degree of importance of the criterion, (D-R) is defined as "relation" indicating effect's magnitude. If the (D-R) is negative then the criterion is grouped into the category of results. It means it is affected by various parameters. If (D-R) is positive it means the effect is high. Firstly, it should be improved. A threshold value is calculated in the fourth step, and the IRM is built on a (x,y) graph. To isolate the factor relationship structure, it is advisable to set a threshold value $\alpha$ to filter the minor effects denoted by the factor matrix $\mathrm{T}$. If all of the information from matrix $\mathrm{T}$ changed over to the IRM, the map would be too complex. The decision-maker sets a threshold value $\alpha$ for the degree of influence to minimize the complexity of the IRM: only variables whose influence value in matrix $\mathrm{T}$ is greater than the threshold value $\alpha$ can be chosen and translated into the IRM. The IRM can be shown when the threshold value and relative IRM have been calculated.

\section{RESULTS AND DISCUSSION}

Aggregated expert opinion is obtained as a direct relation matrix as shown in Table-1.

According to the equation (1) the normalized direct influence matrix $\mathrm{N}$ has been calculated.

Next, based on equation (2) the matrix of total relations T has been determined.

Table-2 Direct Relation Matrix

\begin{tabular}{|c|c|c|c|c|c|c|c|c|c|c|c|c|c|c|}
\hline Factors & $\begin{array}{l}\mathrm{F} \\
1\end{array}$ & $\begin{array}{l}F \\
2\end{array}$ & $\begin{array}{l}\mathrm{F} \\
3\end{array}$ & $\begin{array}{l}\mathrm{F} \\
4\end{array}$ & $\begin{array}{l}F \\
5\end{array}$ & $\begin{array}{l}F \\
6\end{array}$ & $\begin{array}{l}F \\
7\end{array}$ & $\begin{array}{l}\mathrm{F} \\
8\end{array}$ & $\begin{array}{l}\mathrm{F} \\
9\end{array}$ & $\begin{array}{l}\mathrm{F} \\
1 \\
0\end{array}$ & \begin{tabular}{l|}
$\mathrm{F}$ \\
1 \\
1
\end{tabular} & \begin{tabular}{c|}
$\mathrm{F}$ \\
1 \\
2
\end{tabular} & \begin{tabular}{l|}
$\mathrm{F}$ \\
1 \\
3
\end{tabular} & $\begin{array}{l}\mathrm{F} \\
1 \\
4 \\
\end{array}$ \\
\hline $\begin{array}{l}\text { Responsiven } \\
\text { ess(F1) }\end{array}$ & 0 & 2 & 3 & 4 & 2 & 1 & 3 & 1 & 1 & 1 & 3 & 3 & 1 & 1 \\
\hline $\begin{array}{l}\text { Reliability of } \\
\text { the 3PL } \\
\text { provider (F2) }\end{array}$ & 2 & 0 & 3 & 3 & 2 & 1 & 2 & 2 & 1 & 3 & 2 & 2 & 0 & 1 \\
\hline $\begin{array}{l}\text { Quality of } \\
\text { operation } \\
\text { (F3) }\end{array}$ & 3 & 2 & 0 & 4 & 3 & 2 & 3 & 3 & 3 & 3 & 3 & 3 & 1 & 1 \\
\hline Cost (F4) & 4 & 2 & 3 & 0 & 2 & 2 & 3 & 2 & 1 & 3 & 1 & 1 & 1 & 1 \\
\hline $\begin{array}{l}\text { Flexibility } \\
\text { (F5) }\end{array}$ & 3 & 3 & 3 & 4 & 0 & 2 & 4 & 3 & 2 & 1 & 2 & 2 & 1 & 1 \\
\hline $\begin{array}{c}\text { Financial } \\
\text { stability (F6) }\end{array}$ & 1 & 2 & 2 & 3 & 2 & 0 & 3 & 3 & 1 & 1 & 2 & 2 & 2 & 3 \\
\hline $\begin{array}{l}\text { Delivery time } \\
\text { (F7) }\end{array}$ & 4 & 3 & 3 & 4 & 3 & 2 & 0 & 4 & 3 & 2 & 3 & 3 & 2 & 1 \\
\hline $\begin{array}{c}\text { Ability to } \\
\text { meet } \\
\text { customer } \\
\text { need(F8) }\end{array}$ & 1 & 2 & 3 & 4 & 2 & 4 & 4 & 0 & 2 & 3 & 3 & 2 & 1 & 1 \\
\hline $\begin{array}{l}\text { Document } \\
\text { accuracy (F9) }\end{array}$ & 2 & 2 & 3 & 2 & 3 & 1 & 3 & 2 & 0 & 1 & 1 & 1 & 1 & 1 \\
\hline
\end{tabular}

\begin{tabular}{|c|c|c|c|c|c|c|c|c|c|c|c|c|c|c|}
\hline $\begin{array}{c}\text { Storage } \\
\text { facilities } \\
\text { (F10) }\end{array}$ & 1 & 1 & 3 & 3 & 2 & 2 & 4 & 3 & 1 & 0 & 2 & 1 & 1 & 2 \\
\hline $\begin{array}{c}\text { Good } \\
\text { communicati } \\
\text { on (F11) }\end{array}$ & 3 & 2 & 2 & 2 & 2 & 1 & 3 & 3 & 1 & 1 & 0 & 1 & 1 & 1 \\
\hline $\begin{array}{c}\text { Attitude } \\
\text { towards } \\
\text { customers } \\
\text { (F12) }\end{array}$ & 3 & 2 & 2 & 2 & 2 & 2 & 3 & 3 & 2 & 1 & 4 & 0 & 1 & 1 \\
\hline $\begin{array}{c}\text { Technical } \\
\text { competence } \\
\text { (F13) }\end{array}$ & 1 & 1 & 2 & 2 & 1 & 1 & 1 & 2 & 1 & 2 & 1 & 1 & 0 & 1 \\
\hline $\begin{array}{c}\text { Reputation } \\
\text { (F14) }\end{array}$ & 1 & 2 & 3 & 3 & 2 & 3 & 3 & 3 & 3 & 2 & 3 & 3 & 2 & 0 \\
\hline
\end{tabular}

Total relation matrix in table- 4 provide information that how one factor affects other. To avoid complexity in relationship of all criteria with each other, the total relations matrix can be viewed with maximum influence based on threshold value decided by authors and expert opinion in present scenario. According to the table-5, the top five factors with highest importance (highest $D+R$ value) values are found to be: Delivery time (F7)-8.483784, Quality of operation(F3)7.746597, Cost (F4)-7.539728, Ability to meet customer needs(F8)- 7.454399 and Flexibility (F5)- 6.771872. The lowest three factors are the Technical competence (F13) -3.687076, Document accuracy (F9) - 5.240684 and Reputation (F14) - 5.522163.The top five factors with the highest (D-R) values are the Reputation (F14) - 1.908388, Financial stability (F6) - 0.344907, Flexibility (F5) 0.322123 , Attitude towards customers (F12)- 0.300857 and Storage facilities (F10) - 0.257752. The lowest three factors are the Cost (F4) - 1.52264, Good communication (F11) -0.72858 and Responsiveness (F1) - -0.50692 .

Table-3 Normalized Relation Matrix

\begin{tabular}{|c|c|c|c|c|c|c|c|c|c|c|c|c|c|c|}
\hline 㟛 & $\begin{array}{l}F \\
1\end{array}$ & $\begin{array}{l}F \\
2\end{array}$ & $\begin{array}{l}F \\
3\end{array}$ & $\begin{array}{l}F \\
4\end{array}$ & 5 & $\begin{array}{c}F \\
6\end{array}$ & $\begin{array}{l}F \\
7\end{array}$ & $\begin{array}{l}F \\
8\end{array}$ & $\begin{array}{l}\text { F } \\
9\end{array}$ & $\begin{array}{l}\mathrm{F} \\
1 \\
0\end{array}$ & $\begin{array}{l}\mathrm{F} \\
1 \\
1\end{array}$ & $\begin{array}{c}F \\
12\end{array}$ & $\begin{array}{c}F \\
13\end{array}$ & $\begin{array}{c}\mathrm{F} \\
14\end{array}$ \\
\hline $\begin{array}{l}F \\
1\end{array}$ & 0 & $\begin{array}{l}0 \\
. \\
0 \\
5\end{array}$ & $\begin{array}{c}0 . \\
08\end{array}$ & $\begin{array}{l}0 . \\
1 \\
1\end{array}$ & $\begin{array}{l}0 \\
5 \\
\end{array}$ & $\begin{array}{c}0 . \\
03\end{array}$ & $\begin{array}{c}0 . \\
08\end{array}$ & $\begin{array}{l}0 \\
\dot{0} \\
0 \\
3\end{array}$ & $\begin{array}{l}0 \\
\dot{0} \\
0 \\
3\end{array}$ & $\begin{array}{c}0 . \\
0 \\
3\end{array}$ & $\begin{array}{l}0 \\
\dot{0} \\
0 \\
8\end{array}$ & $\begin{array}{c}0 . \\
08\end{array}$ & $\begin{array}{c}0 . \\
03\end{array}$ & $\begin{array}{c}0 . \\
03\end{array}$ \\
\hline $\begin{array}{l}F \\
2\end{array}$ & $\begin{array}{l}0 . \\
0 \\
5\end{array}$ & 0 & $\begin{array}{c}0 . \\
08\end{array}$ & $\begin{array}{l}0 . \\
0 \\
8\end{array}$ & $\begin{array}{l}0 \\
5\end{array}$ & $\begin{array}{c}0 . \\
03\end{array}$ & $\begin{array}{c}0 . \\
05\end{array}$ & $\begin{array}{l}0 \\
\text {. } \\
5\end{array}$ & $\begin{array}{l}0 \\
0 \\
0 \\
3\end{array}$ & $\begin{array}{c}0 . \\
0 \\
8\end{array}$ & $\begin{array}{l}0 \\
5\end{array}$ & $\begin{array}{c}0 . \\
05\end{array}$ & 0 & $\begin{array}{c}0 . \\
03\end{array}$ \\
\hline $\begin{array}{l}F \\
3\end{array}$ & $\begin{array}{l}0 . \\
0 \\
8\end{array}$ & $\begin{array}{l}0 \\
. \\
0 \\
5\end{array}$ & 0 & $\begin{array}{l}0 . \\
1 \\
1\end{array}$ & $\begin{array}{l}0 \\
8\end{array}$ & $\begin{array}{c}0 . \\
05\end{array}$ & $\begin{array}{c}0 . \\
08\end{array}$ & $\begin{array}{l}0 \\
. \\
0 \\
8\end{array}$ & $\begin{array}{l}0 \\
0 \\
0 \\
8\end{array}$ & $\begin{array}{l}0 . \\
0 \\
8\end{array}$ & $\begin{array}{l}0 \\
8 \\
\end{array}$ & $\begin{array}{c}0 . \\
08\end{array}$ & $\begin{array}{c}0 . \\
03\end{array}$ & $\begin{array}{c}0 . \\
03\end{array}$ \\
\hline $\begin{array}{l}F \\
4\end{array}$ & $\begin{array}{c}0 . \\
1 \\
1\end{array}$ & $\begin{array}{l}0 \\
. \\
0 \\
5\end{array}$ & $\begin{array}{c}0 . \\
08\end{array}$ & 0 & $\begin{array}{l}0 \\
5 \\
\end{array}$ & $\begin{array}{c}0 . \\
05\end{array}$ & $\begin{array}{c}0 . \\
08\end{array}$ & $\begin{array}{l}0 \\
. \\
0 \\
5\end{array}$ & $\begin{array}{l}0 \\
. \\
0 \\
3\end{array}$ & $\begin{array}{c}0 . \\
0 \\
8\end{array}$ & $\begin{array}{l}0 \\
3 \\
\end{array}$ & $\begin{array}{c}0 . \\
03\end{array}$ & $\begin{array}{c}0 . \\
03\end{array}$ & $\begin{array}{c}0 . \\
03\end{array}$ \\
\hline $\begin{array}{l}F \\
5\end{array}$ & $\begin{array}{l}0 . \\
0 \\
8\end{array}$ & $\begin{array}{l}0 \\
0 \\
0 \\
8\end{array}$ & $\begin{array}{c}0 . \\
08\end{array}$ & $\begin{array}{l}0 . \\
1 \\
1\end{array}$ & 0 & $\begin{array}{c}0 . \\
05\end{array}$ & $\begin{array}{c}0 . \\
11\end{array}$ & $\begin{array}{l}0 \\
0 \\
0\end{array}$ & $\begin{array}{l}0 \\
. \\
0 \\
5\end{array}$ & $\begin{array}{c}0 . \\
0 \\
3\end{array}$ & $\begin{array}{l}0 \\
5\end{array}$ & $\begin{array}{c}0 . \\
05\end{array}$ & $\begin{array}{c}0 . \\
03\end{array}$ & $\begin{array}{c}0 . \\
03\end{array}$ \\
\hline $\begin{array}{l}F \\
6\end{array}$ & $\begin{array}{l}0 . \\
0 \\
3\end{array}$ & $\begin{array}{l}0 \\
5\end{array}$ & $\begin{array}{c}0 . \\
05\end{array}$ & $\begin{array}{c}0 . \\
0 \\
8\end{array}$ & $\begin{array}{l}0 \\
5\end{array}$ & 0 & $\begin{array}{c}0 . \\
08\end{array}$ & $\begin{array}{l}0 \\
0 \\
0\end{array}$ & $\begin{array}{l}0 \\
0 \\
0 \\
3\end{array}$ & $\begin{array}{c}0 . \\
0 \\
3\end{array}$ & 0 & $\begin{array}{c}0 . \\
05\end{array}$ & $\begin{array}{c}0 . \\
05\end{array}$ & $\begin{array}{c}0 . \\
08\end{array}$ \\
\hline $\begin{array}{l}\mathrm{F} \\
7\end{array}$ & $\begin{array}{c}0 . \\
1 \\
1\end{array}$ & $\begin{array}{l}0 \\
8\end{array}$ & $\begin{array}{c}0 . \\
08\end{array}$ & $\begin{array}{l}0 . \\
1 \\
1\end{array}$ & $\begin{array}{l}0 \\
8\end{array}$ & $\begin{array}{c}0 . \\
05\end{array}$ & 0 & $\begin{array}{l}\dot{1} \\
1\end{array}$ & $\begin{array}{l}0 \\
0 \\
0\end{array}$ & $\begin{array}{l}0 . \\
0 \\
5\end{array}$ & $\begin{array}{l}0 \\
8\end{array}$ & $\begin{array}{c}0 . \\
08\end{array}$ & $\begin{array}{c}0 . \\
05\end{array}$ & $\begin{array}{c}0 . \\
03\end{array}$ \\
\hline
\end{tabular}




\begin{tabular}{|c|c|c|c|c|c|c|c|c|c|c|c|c|c|c|}
\hline $\begin{array}{l}F \\
8\end{array}$ & $\begin{array}{l}0 . \\
0 \\
3\end{array}$ & $\begin{array}{l}0 \\
. \\
0 \\
5\end{array}$ & $\begin{array}{c}0 . \\
08\end{array}$ & $\begin{array}{c}0 . \\
1 \\
1\end{array}$ & $\begin{array}{l}0 \\
0 \\
0 \\
5\end{array}$ & $\begin{array}{c}0 . \\
11\end{array}$ & $\begin{array}{c}0 . \\
11\end{array}$ & 0 & $\begin{array}{l}0 \\
5\end{array}$ & $\begin{array}{l}0 . \\
0 \\
8\end{array}$ & $\begin{array}{l}0 \\
. \\
0 \\
8\end{array}$ & $\begin{array}{c}0 . \\
05\end{array}$ & $\begin{array}{c}0 . \\
03\end{array}$ & $\begin{array}{c}0 . \\
03\end{array}$ \\
\hline $\begin{array}{l}F \\
9\end{array}$ & $\begin{array}{c}0 . \\
0 \\
5\end{array}$ & $\begin{array}{l}0 \\
\dot{0} \\
5\end{array}$ & $\begin{array}{c}0 . \\
08\end{array}$ & $\begin{array}{l}0 . \\
0 \\
5\end{array}$ & $\begin{array}{l}0 \\
\dot{0} \\
8\end{array}$ & $\begin{array}{c}0 . \\
03\end{array}$ & $\begin{array}{c}0 . \\
08\end{array}$ & $\begin{array}{l}0 \\
0\end{array}$ & 0 & $\begin{array}{l}0 . \\
0 \\
3\end{array}$ & $\begin{array}{l}0 \\
\dot{0} \\
3\end{array}$ & $\begin{array}{c}0 . \\
03\end{array}$ & $\begin{array}{c}0 . \\
03\end{array}$ & $\begin{array}{c}0 . \\
03\end{array}$ \\
\hline $\begin{array}{l}F \\
1 \\
0\end{array}$ & $\begin{array}{l}0 \\
.0\end{array}$ & $\begin{array}{l}0 \\
. \\
0 \\
3\end{array}$ & $\begin{array}{c}0 . \\
08\end{array}$ & $\begin{array}{l}0 . \\
0 \\
8\end{array}$ & $\begin{array}{l}0 \\
. \\
0 \\
5\end{array}$ & $\begin{array}{c}0 . \\
05\end{array}$ & $\begin{array}{c}0 . \\
11\end{array}$ & $\begin{array}{l}0 \\
8 \\
\end{array}$ & $\begin{array}{l}\dot{0} \\
3 \\
\end{array}$ & 0 & $\begin{array}{l}0 \\
0 \\
0 \\
5\end{array}$ & $\begin{array}{c}0 . \\
03\end{array}$ & $\begin{array}{c}0 . \\
03\end{array}$ & $\begin{array}{c}0 . \\
05\end{array}$ \\
\hline $\begin{array}{l}\mathrm{F} \\
1 \\
1\end{array}$ & $\begin{array}{c}0 . \\
0 \\
8\end{array}$ & $\begin{array}{l}0 \\
0 \\
0 \\
5\end{array}$ & $\begin{array}{c}0 . \\
05\end{array}$ & $\begin{array}{l}0 . \\
0 \\
5\end{array}$ & $\begin{array}{l}\dot{0} \\
5\end{array}$ & $\begin{array}{c}0 . \\
03\end{array}$ & $\begin{array}{c}0 . \\
08\end{array}$ & $\begin{array}{l}0 \\
8\end{array}$ & $\begin{array}{l}0 \\
3\end{array}$ & $\begin{array}{c}0 . \\
0 \\
3\end{array}$ & 0 & $\begin{array}{c}0 . \\
03\end{array}$ & $\begin{array}{c}0 . \\
03\end{array}$ & $\begin{array}{c}0 . \\
03\end{array}$ \\
\hline $\begin{array}{l}\mathrm{F} \\
1 \\
2\end{array}$ & $\begin{array}{l}0 . \\
0 \\
8\end{array}$ & $\begin{array}{l}0 \\
0 \\
0 \\
5\end{array}$ & $\begin{array}{c}0 . \\
05\end{array}$ & $\begin{array}{l}0 . \\
0 \\
5\end{array}$ & $\begin{array}{l}0 \\
5\end{array}$ & $\begin{array}{c}0 . \\
05\end{array}$ & $\begin{array}{c}0 . \\
08\end{array}$ & $\begin{array}{l}0 \\
8\end{array}$ & $\begin{array}{l}0 \\
5 \\
\end{array}$ & $\begin{array}{l}0 . \\
0 \\
3\end{array}$ & $\begin{array}{l}0 \\
1 \\
1 \\
1\end{array}$ & 0 & $\begin{array}{c}0 . \\
03\end{array}$ & $\begin{array}{c}0 . \\
03\end{array}$ \\
\hline $\begin{array}{l}F \\
1 \\
3 \\
\end{array}$ & $\begin{array}{c}0 . \\
0 \\
3 \\
\end{array}$ & $\begin{array}{l}0 \\
0 \\
0\end{array}$ & $\begin{array}{c}0 . \\
05\end{array}$ & $\begin{array}{c}0 . \\
0 \\
5\end{array}$ & $\begin{array}{l}0 \\
0 \\
0\end{array}$ & $\begin{array}{c}0 . \\
03\end{array}$ & $\begin{array}{c}0 . \\
03\end{array}$ & 0 & 0 & $\begin{array}{l}0 . \\
0 \\
5 \\
\end{array}$ & $\begin{array}{l}0 \\
0 \\
0\end{array}$ & $\begin{array}{c}0 . \\
03\end{array}$ & 0 & $\begin{array}{c}0 . \\
03\end{array}$ \\
\hline
\end{tabular}

\begin{tabular}{|c|c|c|c|c|c|c|c|c|c|c|c|c|c|c|}
\hline & & 3 & & & 3 & & & 5 & 3 & & 3 & & & \\
\hline $\mathrm{F}$ & 0. & 0 & & 0. & 0 & & & 0 & 0 & 0. & 0 & & & \\
1 & 0 &. & 0. & 0 &. & 0. & 0. &. &. & 0 &. & 0. & 0. & 0 \\
4 & 3 & 0 & 08 & 0 & 0 & 08 & 08 & 0 & 0 & 5 & 0 & 08 & 05 & 0 \\
& 5 & & 8 & 5 & & & 8 & 8 & & 8 & & & \\
\hline
\end{tabular}

As per Table-5, the causal graph mapping the dataset (D+R, D-R) of the variables and 14 factors in terms of (D+R) (represented along the $\mathrm{X}$-axis) and (D-R) (represented along the $\mathrm{Y}$-axis) are depicted in Figure-1.From the data presented in Table-5, it is noted that the "delivery time" with the most net worthy estimation of $(D+R)$ has most associations with different elements, showing its indispensable role among the picked measures. Moreover, in table-5, Reputation (F14) has the highest (D-R) esteem dispatches the most influence on the other factors, and it is observed to be the main the "main cause- factor" among the factors whereas "Cost" with the lease (D-R) esteem, gets the most influence from the other factors, and it is then considered as the "main effect- factor" among the factors.

Table-4 Total Relation Matrix

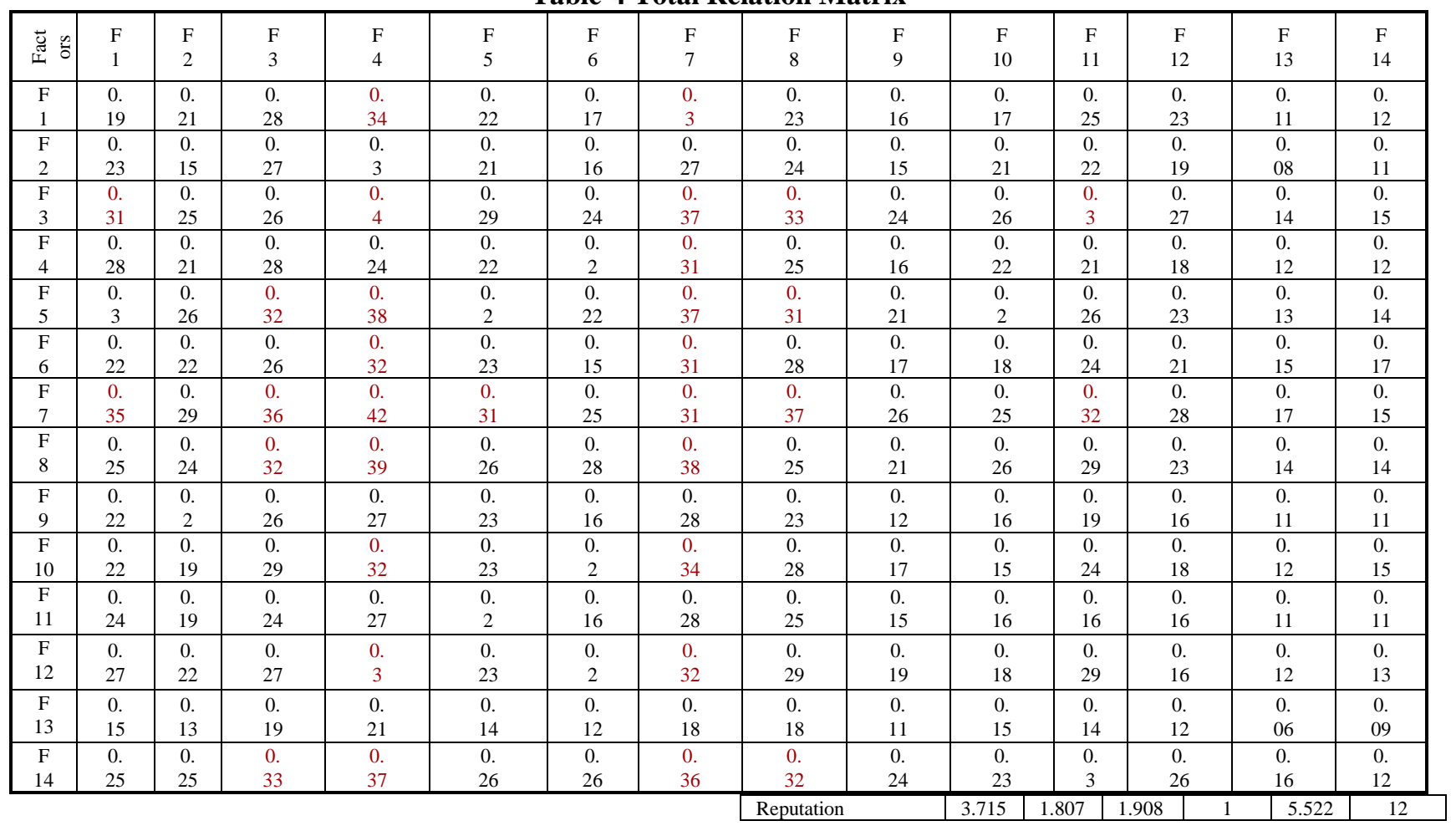

Table-5 Summary of results of DEMATEL analysis

\begin{tabular}{|l|l|l|l|c|c|c|}
\hline \multicolumn{1}{|c|}{ Factors } & D & R & D-R & Rank & D+R & Rank \\
\hline Responsiveness & 2.98 & 3.487 & -0.51 & 12 & 6.467 & 6 \\
\hline $\begin{array}{l}\text { Reliability of the 3PL } \\
\text { provider }\end{array}$ & 2.796 & 3.018 & -0.22 & 10 & 5.815 & 11 \\
\hline Quality of operation & 3.817 & 3.93 & -0.11 & 8 & 7.747 & 2 \\
\hline Cost & 3.009 & 4.531 & -1.52 & 14 & 7.54 & 3 \\
\hline Flexibility & 3.547 & 3.225 & 0.322 & 3 & 6.772 & 5 \\
\hline Financial stability & 3.112 & 2.767 & 0.345 & 2 & 5.878 & 10 \\
\hline Delivery time & 4.1 & 4.384 & -0.28 & 11 & 8.484 & 1 \\
\hline $\begin{array}{l}\text { Ability to meet } \\
\text { customer needs }\end{array}$ & 3.64 & 3.814 & -0.17 & 9 & 7.454 & 4 \\
\hline Document accuracy & 2.702 & 2.539 & 0.163 & 7 & 5.241 & 13 \\
\hline Storage facilities & 3.069 & 2.811 & 0.258 & 5 & 5.879 & 9 \\
\hline Good communication & 2.682 & 3.411 & -0.73 & 13 & 6.093 & 7 \\
\hline $\begin{array}{l}\text { Attitude towards } \\
\text { customers }\end{array}$ & 3.179 & 2.878 & 0.301 & 4 & 6.056 & 8 \\
\hline $\begin{array}{l}\text { Technical } \\
\text { competence }\end{array}$ & 1.97 & 1.717 & 0.253 & 6 & 3.687 & 14 \\
\hline
\end{tabular}

Retrieval Number: F1500089620/2020@BEIESP

DOI: 10.35940/ijeat.F1500.089620

Journal Website: www.ijeat.org
From Fig-1, F14 affects F7. From the influential relationships, third-party logistics industry should improve their reputation. F7 (Delivery time) will be improved. F5 affects F7.3PL industry should improve F5 (flexibility). F7 (Delivery time) will be improved. F12 affects F7.3PL firms must improve their attitude towards customers (F12). F7 (Delivery time) will be improved. F7 affects F4.3PL firms should improve the delivery time (F7). Cost (F4) will be improved. F3 affects F4.3PL firms should improve their quality of operations (F3). Cost (F4) will be improved. F3 affects F7. 3PL firms should improve their quality of operations (F3). F7(Delivery time) will be improved. F8 affects F4.3PL firms should focus on ability to meet customer needs (F8).

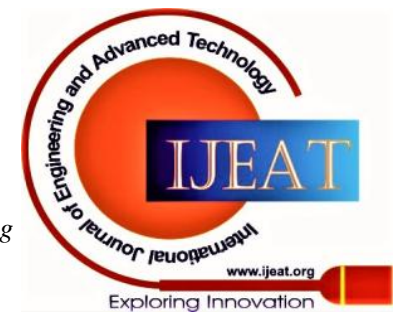


Cost (F4) will be improved. F1 affects F4.3PL firms should improve their responsiveness (F1). Cost (F4) will be improved. [The report is based on Weng. K; 2015.].

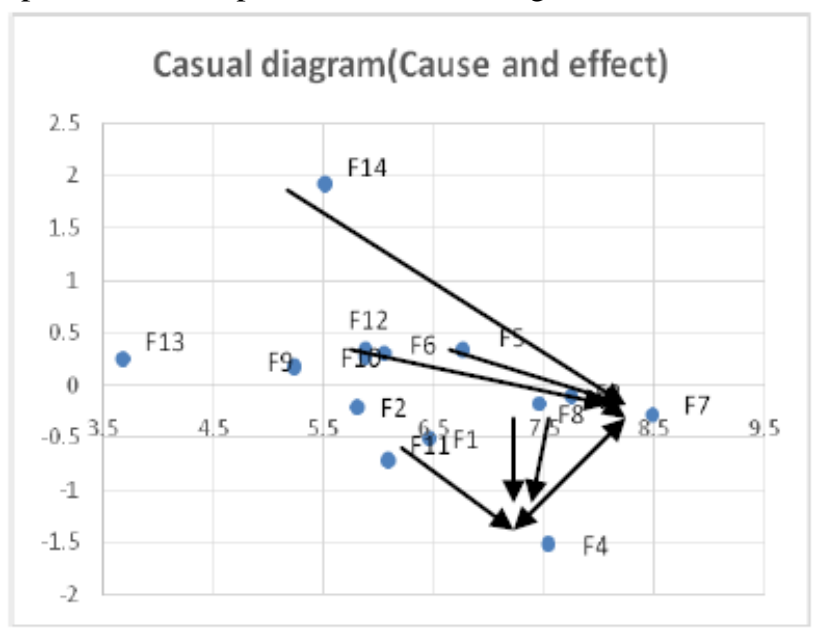

Figure-1

Threshold $=0.3$

\section{CONCLUSION}

This article expresses DEMATEL as the most efficient and logical tool to be utilized during decision-making where the interrelationship between factors is clear. From the investigation, it is noted that in the 3PL industry, the "delivery time" followed by quality and cost are highly significant. These parameters have most connections with other variables, suggesting their vital position among the chosen measures. Reputation has the strongest influence on the other factors. While taking in to consideration the strong influence of reputation, one should not ignore level of financial stability and flexibility. In addition, the attitude and the technical competency are also emerged as important influencer at next level. However, the interpretation of the outcome shows that cost is affected the most among the other variables. Finally, from the overall review, it can be concluded that the delivery performance, quality, cost and reputation are the key requirements in the sector under consideration. The findings of this study will help decision-makers make better choices in Abu Dhabi, UAE and world 3PL market.

\section{REFERENCES}

1. M.S. Sohail, S.A. Anwar, J. Chowdhury, and N.R. Farhat, "Logistics Outsourcing in the United Arab Emirates", Journal of Marketing Channels, 13(1), pp. 21-36,2006.

2. R. Rajesh, S. Pugazhendhi and K. Ganesh," A study on third party logistics in India”, Int.J.Indian culture and Business management, Vol.7, No.1, 2013.

3. Detcharat Sumrit ,Pongpun Anuntavoranich," Using DEMATEL Method to Analyze the Causal Relations on Technological Innovation Capability Evaluation Factors in Thai Technology-Based Firms", International Transaction Journal of Engineering, Management, \& Applied Sciences \& Technologies,pp.81-103,2013.

4. Kannan. G, Atanu. C," Interrelationships of risks faced by third party logistics service providers: A DEMATEL based approach", Transportation research part E,2016.

5. Betty.C, Chih-Wei.C, Chih-Hung.W," Fuzzy DEMATEL method for developing supplier selection criteria”, Expert system with applications,38, pp.1850-1858,2011.

6. Chia-Wei Hsu, Tsai-Chi kuo, Sheng-Hung Chen, Allen H.Hu,’Using DEMATEL to develop a carbon management model of supplier selection in green supply chain management",Jounal of cleaner production,56,pp.164-172,2013.
7. L. Abdullah, R. Ramli, H.O. Bakodah, M. Othman," Developing a causal relationship among factors of e-commerce: A decision making approach", Journal of King Saud University-Computer and Information sciences,2019.

8. EB Leksono , Suparno , I Vanan," Using DEMATEL approach to develop relationships of performance indicators on sustainable service only supply chain performance measurement”, IOP Conf. Series: Materials Science and Engineering,33,2018.

9. Ejder Ayçin, "A Grey DEMATEL Integrated Approach to Determine Third Party Logistics Service Provider Selection Criteria", The Journa of Operations Research, Statistics, Econometrics and Management Information Systems, Volume 6, Issue 2, 2018.

10. Katerina Kashi," DEMATEL method in practice: Finding the causal relations among key competencies", The 9th International Days of Statistics and Economics, Prague, September 10-12, pp.723-732, 2015.

\section{AUTHORS PROFILE}

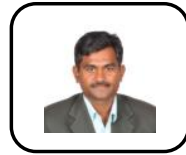

R.Ashok is a Research Scholar,Noorul Islam Higher Education,Kumaracoil,Tamilnadu. He did his Bachelor of Mechanical Engineering in 1997 and Master of Production Engineering in 1999.He has more than 6 years of Teaching experience in India and 13 years Industry experience in Qatar and UAE.He has attended several Internationa Conferences and Workshops and published 5 papers in International journals.

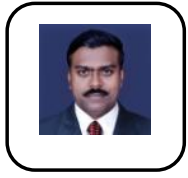

Dr. R. Rajesh working as a Principal in Rohini College of Engineering and Technology, Anjugrammam, India. He has more than 22 years' experience in Teaching. He has published 125 papers in International and National journals

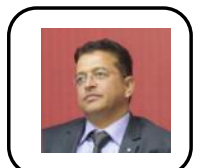

Dr. Surender Kumar working as an Assistant Professor (Business Analytics and Decision Sciences) Jaipuria Institute of Management, Noida, India. He has around sixteen years of experience in research and academics. He has published 22 research papers in the various journals of National and International repute. His areas of research include Stochastic Modeling, Multi Criteria Decision Making, Financial Econometrics, Big Data Analytics, Machine Learning and Artificial Intelligence.

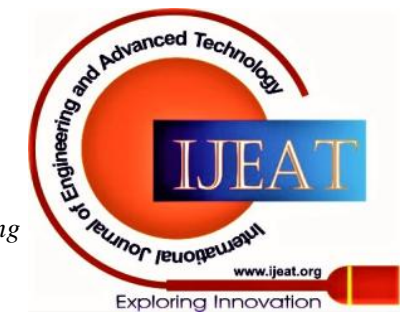

